VOX PATRUM $22(2002)$ t. $42-43$

\author{
Anna Z. ZMORZANKA \\ (Lublin, KUL)
}

\title{
KOBIETA - UCZENNICA I NAUCZYCIELKA W PRZEKAZACH GNOSTYCKICH
}

Herezjologowie chrześcijańscy utrwalili charakterystyczny dla gnostycyzmu topos, przedstawiający nierozłączną parę: nauczyciela-maga i jego towarzyszkę-uczennicę, których symbolem stali się Szymon i Helena ${ }^{1}$. Wydaje się, iż odzwierciedla on relacje, jakie istniały w sektach gnostyckich; pośrednio poświadcza też udział kobiet w gnostyckim nauczaniu.

1. Uczone kobiety u gnostyków. Ireneusz stwierdza stosunkowo duże zainteresowanie kobiet działalnością wywodzącego się z kręgu walentynianów Marka Maga, a także ich zaangażowanie w religijne życie jego sekty (tzw. markozjanów $)^{2}$. $\mathrm{Z}$ tego samego przekazu wiemy też, że wiele kobiet $\mathrm{z}$ najbliższego otoczenia Marka pochodzilo ze znamienitych i bogatych rodzin ${ }^{3}$. Przykład markozjanek wydaje się dobrze ilustrować pod tym względem sytuację innych grup gnostyckich. Dla nas interesujące jest (zwłaszcza) pytanie, czy wśród kobiet wtajemniczanych w gnozę (lub interesujących się nauką gnostycką) były niewiasty wykształcone? Na podstawie zachowanych źródeł można

\footnotetext{
${ }^{1}$ Pierwsze relacje na ich temat znajdujemy u apologetów wczesnochrzescijańskich: Justyna Męczennika (Apologia I 26) i Ireneusza (Adversus haereses I 23,2).

${ }^{2}$ Por. Irenaeus, Adversus haereses I 13, 1-7, SCh 264, 188-204; o działalnosci kobiet w innych sektach heretyckich pisze też Tertulian w De praescriptione haereticorum 41, SCh 46, 147, PSP 5 , 75. O kobietach uczestniczących w sektach gnostyckich zobacz też wzmianki: J. Daniélou, Le mystère des femmes dans l'Église ancienne, „La Maison Dieu” 60 (1960) 80; G. Casadio, Donna e simboli femminili nella gnosi del II secolo, w: La donna nel pensiero cristiano antico, a cura di U. Mattioli, Genova 1992, 305-330; K. Rudolph, Gnoza: istota i historia późnoantycznej formacji religijnej, tłum.. K. Sowiński, Kraków 1995, 186-187 i 204; M. Starowieyski, Kobieta w starożytności chrześcijańskiej, w: Kobieta w kulturze średniowiecznej Europy, Poznań 1999, 31. Zjawisko to potwierdza zauważaną przez historyków „ogólną tendencję większego zainteresowania kobiet religia" w tamtym okresie, zob. W. Myszor, Europa: pierwotne chrzescijanistwo, Warszawa 1999/ $2000,137$.

${ }^{3}$ Ireneusz zwraca uwagę na ich purpurowe szaty, które świadczyłyby o wysokim statusie społecznym, por. Adversus haereses I 13, 3, SCh 264, 194: „Maxime enim circa mulieres vacat, et hoc circa eas quae sunt honestae et circumporpuratae".
} 
wskazać jedynie trzy konkretne postacie. Pierwszą była „droga siostra” Flora, do której walentynianin Ptolomeusz skierował list stanowiący wykładnię Prawa Mojżeszowego ${ }^{4}$, drugą Flawia Sophe, posiadająca wysoki stopień wtajemniczenia w gnozę, o czym świadczy zachowana inskrypcja nagrobna ${ }^{5}$, trzecią według relacji Ireneusza, Marcelina uczennica przedstawiciela gnozy egipskiej - Karpokratesa ${ }^{6}$, który uważany był za jednego $\mathrm{z}$ najlepiej wykształconych gnostyków w zakresie filozofii platońskiej ${ }^{7}$. Należy przypuszczać, że niewiasty podobne do Flory, Flawii i Marceliny nie były wyjątkami, gdyż „studiowanie” nauk gnostyckich (do którego dopuszczano przecież kobiety) wymagało od shuchaczy pewnej znajomości z dziedziny m.in. filozofii, teologii czy egzegezy Pisma świętego.

Jaką rolę uczone gnostyczki pełniły w swoich sektach/gminach? Przede wszystkim, w przeciwieństwie do chrześcijanek w Kościele ortodoksyjnym, w którym niewiasty obowiązywał nakaz milczenia na zgromadzeniach ${ }^{8}$, mogły one nauczać publicznie. Niestety na temat kobiet nauczających u gnostyków posiadamy jeszcze mniej informacji. Tertulian wspomniał jedynie bardzo ogólnie o kobietach nauczających u heretyków ${ }^{9}$. Natomiast Ireneusz (a za nim Epifaniusz) wymienił imiennie tylko jedną nauczającą gnostyczkę, wspomnianą wyżej Marcelinę ${ }^{10}$. Jej działalność przypadła na okres pontyfikatu papieża Aniceta (155-166), kiedy to przybyła do Rzymu, gdzie gloszona przez nią nauka karpokracjańska przyciągnęła, jak informuje Biskup Lyonu, niemałą liczbę słuchaczy: „Marcellina quae Romam sub Aniceto venit cum esset huius doctrinae, multos exterminavit"11. Marcelina jest ważna nie tylko dlatego, ze była jedyną nauczającą u gnostyków kobietą, której imię ocalało od zapomnienia, lecz także $z$ tego powodu, że jako nauczycielka zdobyła pewną popularność. Być może do rzymskiego sukcesu Marceliny przyczyniło się w równym

${ }^{4}$ Najprawdopodobniej Flora też była walentynianką, na co wskazuje wg G. Quispela zwrot:

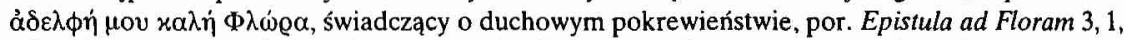
SCh 24bis, 50; zob. też H.A. Green, Ritual in Valentinian Gnosticism: a sociological interpretation, "The Journal of Religious History" 12 (1982/1983) 115.

5 Por. K. Rudolph, dz. cyt., s. 187.

${ }^{6}$ Por. Irenaeus, Adversus haereses I 24, 6, SCh 264, 342; Epiphanius, Panarion I 27, PG 41, 371.

7 O związkach karpokracjańskiej doktryny z platonizmem lub pitagoreizmem świadczyć może przyjście Jednego (lub Jedynki) jako podstawowego/nadrzędnego pryncypium, por. Epiphanius, Panarion I 27, PG 41, 363.

${ }^{8}$ Nakaz taki pojawił się już w Listach $\leqslant$ w. Pawla (np. 1 Kor 14, 34) i utrzymywał w następnych wiekach, co potwierdzają: Tertullianus, De virginibus velandis 9,2; Origenes, In Isaiam hom. VI 3 oraz Didascalia III 6, 1-2. Na temat zakazu publicznego wypowiadania się kobiet w Kościele zob. też.: J. Załęski, Czy kobiety powinny milczeć w Kościele?: (1Kor 14, 34-35), CT 67 (1997) nr 4, 5-20, oraz W. Myszor, dz. cyt., s. 143-146.

${ }^{9}$ Por. De praescriptione 41 , SCh 46, 147, PSP 5, 75.

${ }^{10}$ Por. Adversus haereses I 24, 6, SCh 264, 342; Epiphanius, Panarion I 27, PG 41, 371.

${ }^{11}$ Adversus haereses I 24, 6, SCh 264, 342. 
stopniu wtajemniczenie w gnozę, jak i znajomość filozofii (zwłaszcza platońskomisteryjnej), jaką zdobyła jako uczennica Karpokratesa. To pozwala też dostrzec w jej osobie kontynuatorkę tradycji uczonych filozofek oraz prekursorkę słynnych neoplatonek, które pojawiły się w następnych wiekach ${ }^{12}$.

Co zdecydowało o tym, że gnostyczki osiągały w swoich kręgach tak wysoką pozycję? Wydaje się, iż w zależności od terytorium oraz typu szkoły, decydować mogły różne czynniki. Jednym z nich mógt być fakt, że - tak jak miało to miejsce np. w Egipcie - gnoza przenikała do kręgów filozofów platońskich i neopitagorejskich, w których kobiety (takie jak Marcelina i być może Flora) posiadały ustaloną już pozycję. Okoliczności sprzyjające stwarzała też płynna struktura gminy (co potwierdza przykład walentynianów ${ }^{13}$ ), a brak ostrego podziału (jaki istnial już w Kościele ortodoksyjnym) na kler i laikat dawał wszystkim członkom wspólnoty większą swobodę wypowiadania ${ }^{14}$. Najważniejsze jednak było to, że w przekazywaniu gnozy płeć nie stanowiła decydującego kryterium. Potwierdzają to teksty gnostyckie, które rzucają nowe światlo na interesującą nas kwestię udziału i roli kobiet w nauczaniu u gnostyków.

2. Uczennice Chrystusa. Wiele pism gnostyckich potwierdza przekazany przez herezjologów topos mistrza i uczennicy. Jest on obecny w Ewangelii Tomasza, Ewangelii Filipa, Madrości Jezusa Chrystusa, Dialogu Zbawcy, I Apokalipsie Jakuba, Ewangelii Marii i Pistis Sofii ${ }^{15}$. Celem wymienionych utworów jest przekazanie ezoterycznej nauki samego Jezusa, kierowanej do wybranego grona, składającego się z mężczyzn i kobiet. Nauka Zbawcy (słowa przekazywane potajemnie) przekazywana była najczęściej według schematu: „pytanie ucznia - odpowiedź nauczyciela", przybierając formę prostego dialogu ${ }^{16}$.

Obecność kobiet w gronie słuchaczy zaznacza się najwyraźniej (w Ewangelii Tomasza, Mqdrości Jezusa Chrystusa, Dialogu Zbawcy, Ewangelii Marii czy Pistis Sofia), gdy zadają Jezusowi/Zbawcy pytania. O ich obecności w tym gronie

${ }^{12}$ Bliska jej wydaje się byćc zwłaszcza neoplatonka żyjąca w III wieku Sozypatra, która otrzymawszy wtajemniczenie w praktyki chaldejskie, nauczała filozofii połączonej z teurgią. Na jej temat zob. M. Dzielska, Hypatia z Aleksandrii, Kraków 1993, 22 oraz P. Rousseau, ,Learned Women" and the development of a Christian Culture in Late Antiquity, „Symbolae Osloenses" 70 (1995) 118-119.

${ }_{13}$ Por. Tertullianus, De praescriptione 41, SCh 46, 147, PSP 5, 75; zob. też H.A. Green, dz. cyt., s. 109-124.

${ }^{14}$ Por. K. Rudolph, dz. cyt., s. 189-190.

${ }^{15}$ Problematyka ta została szczegółowo omówiona w monografii: A. Marjanen, The woman Jesus loved: Mary Magdalene in the Nag Hammadi literature and related documents (Nag Hammadi and Manichaean Studies 40), Leiden 1986.

${ }^{16} \mathrm{Na}$ temat tej formy wypowiedzi w tekstach gnostyckich por. W. Myszor [wstęp i przekl.], Ewangelia Marii, STV 13 (1979) nr 2, 150 (dalej cyt.: W. Myszor, Ewangelia Marii) oraz tenże, Biblioteka z Nag Hammadi: formy literackie, VoxP18 (1998) t. 34-35, 327-328. 
dowiadujemy się też z relacji innych uczniów lub samego autora pisma. W I Apokalipsie Jakuba sygnalizuje ją pytanie o kobiety towarzyszące Jezusowi, z którym Jakub zwraca się do samego Zbawcy ${ }^{17}$. Autor Ewangelii Filipa, nawiązując do działalności Jezusa (w Galilei), wspomina stale towarzyszące Mu niewiasty „trzy Marie"18. Zaś autor Mądrości Jezusa Chrystusa już na samym wstępie wspomina o siedmiu kobietach (cacyq€ NC2 IME), które razem z dwunastoma uczniami (TCNOOYC MмденTHC) przybyly słuchać tajemnej nauki Pana:
„Po jego zmartwychwstaniu, dwunastu uczniów i siedem kobiet, nieustających w jego naśladowaniu, przybyło do Galilei na górę nazywaną «Przepowiadanie i Radośč, kiedy oni zebrali się razem, zostali wprawieni w zakłopotanie z powodu niepojętej rzeczywistości wszechświata, i przeznaczenia, i świętej opatrzności, i mocy zarząd- ców, i z powodu tego wszystkiego, co Zbawca czynił z nimi w tajemnicy"19.

Informacja o siedmiu kobietach pojawia się jeszcze tylko w I Apokalipsie Ja$k u b a^{20}$. Liczba ta (podobnie jak "dwunastka” określająca liczbę uczniów) ma przede wszystkim znaczenie umowne i oznaczać może, tak jak w Ewangelii Łukasza 8, 1, kilka (a nawet kilkanaście) niewiast: „Następnie wędrował [....] nauczając i głosząc Ewangelię o królestwie Bożym. A było z nim Dwunastu oraz kilka kobiet"21.

Na uwagę zasługuje fakt, iż w Ewangeliach kanonicznych termin $\mu \alpha \theta \dot{\eta} \tau \varrho \iota \alpha$ jeszcze nie występował ${ }^{22}$; ewangeliści piszą jedynie, że kobiety towarzyszyły Jezusowi, gdy nauczal ${ }^{23}$, podobne określenia (w odniesieniu do kobiet) spotykamy też w tekstach gnostyckich (np. w Ewangelii Filipa II 3: 59,6-7). Okreś-

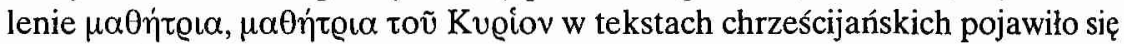
po raz pierwszy dopiero w pol. II wieku w apokryficznej Ewangelii Piotra w odniesieniu do Marii Magdaleny ${ }^{24}$. Mniej więcej w tym samym czasie zro-

${ }^{17}$ Por. NHC V 4: 40, 22-26, Nag Hammadi Studies: The Coptic Gnostic Library (= NHS: CGL) 11, ed. D.M. Parrott, Leiden 1978, 99.

${ }_{18}$ Por. NHC II 3: 59, 5-9, Teksty z Nag Hammadi, z języka koptyjskiego thum. A. DembskaW. Myszor; PSP 20, 247.

19 NHC III 4: 90, 14 - 91, 9, NHS: CGL 27, ed. D.M. Parrott, Leiden 1991, 37.

${ }^{20}$ Por. NHC V 4: 38, 16-18, NHS: CGL 11, 95; zob. też A. Marjanen, dz. cyt., s. 126.

${ }^{21}$ Cytaty wg Biblii Tysiąclecia, Poznań - Warszawa 1980 (wyd.3, poprawione)

22 W Biblii status ucznia przysługiwal jedynie mężczyznom. W odniesieniu do słuchaczy Jezusa termin $\mu \alpha 0 \eta \eta \dot{\zeta} \zeta$ w księgach nowotestamentowych został użyty ok. 250 razy; zob. J. Flis, Konkordancja Starego i Nowego Testamentu do Biblii Tysiqclecia, Warszawa 1991, 1532-1534. Słowo $\mu \alpha \theta \dot{\eta} \tau \varrho \iota \alpha$ pojawiło się jedynie raz w Dziejach Apostolskich w odniesieniu do uczennicy sw. Pawła - Tabity (Dz 9, 36).

${ }^{23}$ Por. Mt 15, 30. 32. 38. O kobietach towarzyszących Jezusowi wspomina też autor Ewangelii Filipa II 3: 59, 6-7; zob. też D.M. Montegna, Le donne di Galilea nel ministero di Cristo, „Servitium” 3 (1969) 245-257.

${ }^{24}$ Por. Ewangelia Piotra XII 50-51, w: Apokryfy Nowego Testamentu, t. I 2, red. M. Starowieyski, Lublin 1980, 418: „W dniu Pańskim o świcie Maria Magdalena uczennica Pana [...] wziąwszy z sobą przyjaciólki udała się do grobu, gdzie został złożony". 
dziła się też idea uczennicy (TMגөHTHC) Pana/Zbawcy w nauczaniu gnostyckim. Potwierdzają to takie teksty jak Ewangelia Tomasza, Ewangelia Filipa i I Apokalipsa Jakuba. W 61 logionie Ewangelii Tomasza Salome, zadając pytanie Jezusowi, nazywa siebie Jego uczennicą: „аNOK тєк Mаөнтнс”25. Autor Ewangelii Filipa określenia tego użył w odniesieniu do Marii Magdaleny, stwierdzając, iż Jezus: „kochał ją bardziej niż wszystkich uczniów”26 Z kolei Jakub, we wspomnianym już fragmencie I Apokalipsy Jakuba, uczennicami nazywa siedem kobiet, które towarzyszyły Panu:

"Co się tyczy innych spraw, pytam Cię: kim jest siedem kobiet, które były twoimi uczennicami?" 27 .

Z siedmiu kobiet wspomnianych w I Apokalipsie Jakuba poznajemy imiona czterech, które wymienia sam Zbawca, mówiąc do Jakuba: „kiedy ty mówisz o tym, co zobaczyłeś, zachęcasz tamte cztery" 28 . Owe „cztery” to: Mariam (MapıaM) - identyfikowana z Marią Magdaleną - nazywana też MapızaM (Ewangelia Tomasza, Dialog Zbawcy) i мapı2amme (Madrość Jezusa Chrystusa $)^{29}$. Trzy pozostałe to: Salome (Ewangelia Tomasza, I Apokalipsa Jakuba, Pistis Sofia), Marta (I Apokalipsa Jakuba, Pistis Sofia) oraz Arsinoe (I Apokalipsa Jakuba). Do grona słuchaczek, których imiona można zidentyfikować, dołączyć należy Marię, matkę Jezusa (w Ewangelii Filipa występuje wśród kobiet, które towarzyszyły Jezusowi, zaś w Pistis Sofia zadaje Zbawcy pytania) ${ }^{30}$. Wszystkie wymienione niewiasty, poza Arsinoe ${ }^{31}$, według przekazu nowotestamentowego, pojawiały się w (najbliższym) otoczeniu Jezusa. Obok nich występują uczniowie noszący imiona biblijnych apostołów: są to Piotr (nazywany też Szymonem Piotrem), Tomasz, Mateusz (w Ewangelii Marii nazwany Lewi $)^{32}$, Andrzej, Jakub, Jan, Bartłomiej i Juda ${ }^{33}$.

${ }^{25}$ NHC II 2: 43, 30-31, PSP 20, 218.

${ }^{26}$ NHC II 3: 63, 34-35, PSP 20, 168.

${ }^{27}$ NHC V, 3: 38, 16-17, NHS: CGL 11, ed. D.M. Parrott, Leiden 1979, 94.

${ }^{28}$ NHC V 3: 40, 22-25, NHS: CGL 11, 98. Zbawca czyni tutaj wyraźną aluzję do wizji, jaką dał Jakubowi.

${ }^{29}$ W Ewangelii Filipa II 3: 59, 6-11 i w Pistis Sofia I-III obok używanych najczęściej form $\mathrm{MapI/2/ \lambda M/M \epsilon /} \mathrm{pojawia} \mathrm{się} \mathrm{też} \mathrm{forma} \mathrm{Maria;} \mathrm{imieniem} \mathrm{tym} \mathrm{nazywana} \mathrm{jest} \mathrm{jednak} \mathrm{przede} \mathrm{wszyst-}$ kim matka Jezusa, por. A. Marjanen, dz. cyt., s. 63-65.

${ }^{30} \mathrm{Na}$ temat roli tej postaci por. W. Myszor, Maryja w wypowiedziach chrześcijańskich gnostyków, WST 10 (1997) 211-217.

${ }^{31}$ Imię to nie jest jednak pewne, zostało zrekonstruowane przez wydawcę tekstu, zob. A. Marjanen, dz. cyt, s. 131.

32 Por. Mk 2, 14 i Mt 9, 9.

${ }^{33}$ Imiona te odnotowują tzw. „katalogi apostołów”: Mt 10, 3-4; Mk 3, 18-19; Łk 6, 14-16, Ordinamentum ecclesiasticum apostolicum i List Apostołów. Imię Lewi w katalogach tych nie jest wymieniane. 
W dialogach ważną funkcję pełnią pytania, jakie zadają uczniowie. Na ogól stanowią one zapowiedź rozwijanego przez Zbawcę tematu. Większość pytań stawiają uczniowie wspólnie ale są też pytania zadawane indywidualnie. Rodzaj oraz ilość zadawanych przez daną postać pytań pozwala określić jej pozycję w gronie uczniów. W Ewangelii Tomasza nie wydaje się, by któraś z płci była szczególnie faworyzowana przez autora. Jedno pytanie stawiają tutaj wspólnie Piotr, Mateusz i Tomasz (logion 13), którzy włączają się też kolejno do wypowiedzi Jezusa; po jednym pytaniu indywidualnie zadają: Piotr (logion 114) oraz Maria Magdalena (logion 21) i Salome (logion 61) . $^{34}$. W Mądrości Jezusa Chrystusa, gdzie występuje nieznaczna przewaga mężczyzn, indywidualnie stawiają pytania: Filip, Mateusz, Tomasz (po dwa) i Bartłomiej (jedno); jedyną kobietą, z grona ,siedmiu”, która zadaje Zbawcy dwa pytania jest Maria Magdalena. W Dialogu Zbawcy te proporcje również są zachowane; pytania stawiają Mateusz (10 razy), Juda (13 razy) i Maria Magdalena (13 razy). W Pistis Sofia I-III zauważa się przewagę Marii Magdaleny ${ }^{35}$, która zadaje Zbawcy aż sześćdziesiąt siedem pytań. Pozostałe czterdzieści osiem pytań przypada na Marię - matkę Jezusa, Salome i Martę oraz Andrzeja, Jakuba, Jana, Mateusza, Piotra, Filipa i Tomasza. Maria Magdalena utrzymuje również przewagę nad mężczyznami (Piotrem, Andrzejem i Lewim) w Ewangelii Marii.

Kim są uczniowie i uczennice Zbawcy i jakie są ich cele? Pytania te, stanowiące jedno $\mathrm{z}$ centralnych zagadnień gnostyckiej soteriologii, pojawiają się w Ewangelii Tomasza, Mądrości Jezusa Chrystusa i Dialogu Zbawcy ${ }^{36}$. Na uwagę zasługuje fakt, iż stawia je kobieta - Maria Magdalena. W Ewangelii Tomasza pyta Jezusa: „Do kogo podobni są twoi uczniowie?”37. Odpowiedź, zawierająca wyraźne aluzje biblijne, jest następująca:

„Podobni są do małych dzieci przebywających na polu, które do nich nie należy”38.

W Mądrości Jezusa Chrystusa Maria Magdalena pyta o pochodzenie uczniów oraz ich cel:

„«Święty Panie, skąd przybyli twoi uczniowie, dokąd oni zmierzają i co powinni tutaj uczynić»? Doskonały Zbawca odpowiedzial im: «Ja chcę, abyście wiedzieli, że Sofia, Matka Wszechrzeczy i Syzygii, sama zapragnęła tamte [rzeczy] powolać

${ }^{34}$ Dwa pytania stawiają też „kobieta z thumu” (logion 79) i „pewien mężczyzna” (logion 72). Pojawienie się tych postaci jest wyraźnie sprzeczne z sekretnym charakterem nauczania. Odpowiedzi jakich udziela Zbawca stanowią wyraźną aluzję do Łk 11, $27-28$ i 47, 9-12; por. W. Myszor, PSP 20, 235-236.

35 Por. A. Marjanen, dz. cyt., s. 174-179.

36 Por. Dialog Zbawcy II 2: 43, 34-44, 1, tamże, s. 218.

37 Ewangelia Tomasza II 2: 36, 34-35, PSP 20, 211.

38 Ewangelia Tomasza II 2: 36, 35-37, 1, PSP 20, 211. W. Myszor za Leidpoldtem stwierdza, iz wypowiedź ta ma sens alegoryczny: dzieci to gnostycy, zaś obce pole to świat, por. PSP 20, 230. 
do istnienia bez swojego męskiego odpowiednika w Syzygii. Ale z woli Ojca Wszechrzeczy, aby jego niewyobrazalne bóstwo nie zostało objawione; On stworzył kurtynę pomiędzy nieśmiertelnymi i tamtymi [...]. Ten, kto pochodzi od Dawcy życia w niewypowiedzianej radości i prawdzie, niech przyniesie mi znaki niewidzialnego Jednego, i on stanie się światłem w Duchu i Ciszy»"39.

W obu przypadkach Zbawca stara się wyjaśnić Marii, iż jego prawdziwymi uczniami mogą być jedynie ci, którzy są obcy w świecie - czyli gnostycy. Objawiając tajemnice ich prawdziwego pochodzenia, wskazuje na Dawcę życia, z którym są zjednoczeni (jedność tą symbolizuje „znak niewidzialnego Jednego"); wyjaśnienie tej kwestii przynoszą dzieje upadku Sofii przedstawione w Mąrości Jezusa Chrystusa (III 3: 114, 9-23). W końcowej części wypowiedzi Zbawca stwierdza, iż celem gnostyckich uczniów jest powrót do „źródła życia” (miejsca pochodzenia); zapewnić im to może przekazywana wiedza (gnoza). W Dialogu Zbawcy pytanie Marii Magdaleny o sens swojej misji jako uczennicy (,Z jakiego powodu przybyłam do tego miejsca? Czy aby zyskać, czy by stracić?") ${ }^{40}$ ma bardziej praktyczny cel. Podobny charakter ma też odpowiedź Zbawcy, który powierza jej misję wyjaśniania jego objawienia („Ty uczynisz jasnym bogactwo objawienia") ${ }^{41}$.

W kontekście powyższych wypowiedzi zastanawiają antyfeministyczne postawy, jakie w Ewangelii Tomasza oraz Ewangelii Marii prezentują Piotr i Andrzej. Ich wystąpienia ujawniają przede wszystkim społeczne tło konflik$\mathrm{tu}^{42}$. Najostrzejszą formę przybiera on w Ewangelii Tomasza. W ostatnim (114) logionie Piotr domaga się bowiem wykluczenia kobiet z grupy (atak ten kieruje bezpośrednio ku Marii Magdalenie): „Rzekł Szymon Piotr do nich: «niech Mariam odejdzie od nas. Kobiety nie są godne życia»" ${ }^{43}$. Obrona Marii, której podejmuje się sam Jezus, odwołuje się do nauki o upadku Sofii oraz do gnostyckiej soteriologii. W ich świetle pleć jest wynikiem upadku, który spowodowal (wszelki) podział; pokonać go może odrodzenie człowieka duchowego (które zjednoczy w nim ponownie to, co męskie i to, co żeńskie); dokonuje się ono przez poznanie (gnozę), której udziela Zbawca:

„Rzekł Jezus: «Oto poprowadzę ją, aby uczynić ją mężczyzną, aby stała się sama duchem żywym, podobnym do was mężczyzn. Każda kobieta, która uczyni siebie mężczyzną, wejdzie do królestwa niebios»" "44.

${ }^{39}$ NHC III 3: 114, 9-23; 117, 5-21, NHC: CGL 27, 169 i 174-175.

${ }^{40}$ NHC III 5: 140, 14-16, NHS: CGL 26, ed. S. Emmel, Leiden 1984, 80.

${ }^{41}$ NHC III 5: 140, 17-18, tamże.

42 Por. A. Marjanen, dz. cyt., s. 119-121.

${ }^{43}$ NHC II 2, 51, 19-20, PSP 20, 226.

44 NHC II 2: 51, 20-28, PSP 20, 226; paralelna wypowiedź znajduje się w Ewangelii Filipa II 3: 70,9-22, PSP 20, 259-260. 
W podobnej sytuacji znajdują się mężczyźni, co pokazuje logion $22 .^{45}$. W Ewangelii Marii źródłem konfliktu staje się fakt, iż to Marii (Magdalenie), a nie uczniom, Zbawca objawił tajemne prawdy. Wystąpienie Piotra i Andrzeja tylko pozornie nie jest skierowane przeciwko Marii, jako kobiecie. Obaj uczniowie zarzucają jej bowiem, że nieprawdziwie przekazuje słowa Pana, starając się tym samym wzbudzić wątpliwość, co do wiarygodności jej nauczania:

„Odezwał się zaś Andrzej i rzekł do braci: «Powiedzcie, co sądzicie o tym, co powiedziała. Ja doprawdy nie wierzę, aby Zbawca to mówil. Zaiste, te pouczenia, to były inne myśli». Odezwał się Piotr mówiąc o rozumieniu spraw tego rodzaju, zapytał o nie w odniesieniu do Zbawcy: «Czy mówil on z niewiastą potajemnie przed nami, nie zaś otwarcie? Czy my sami mamy się nawrócić i wszyscy słuchać jej? Czy on wybral ją bardziej niż nas?»"46.

Obrońcą Marii jest Lewi, który upomina Piotra:

„Piotrze, od dawna jesteś zagniewany, teraz widzę, że dręczysz kobietę jak przeciwnicy. Jeśli Zbawca uznał ją za godną, kim więc jesteś ty sam, że ją odrzucasz?"47

Piotr i Andrzej, reprezentujący postawę tradycyjną (wobec kobiet), niechętnie przyznają niewieście prawo do pouczania ich w kwestiach wiary ${ }^{48}$. Lewi, a także sama Maria, prezentują nowe stanowisko (bliskie gnostykom): kobieta, tak samo jak mężczyzna, ma prawo do nauczania, jeśli stoi za tym autorytet Nauczyciela (Mistrza).

3. Apostola gnosticorum. Źródeł wyróżnienia Marii Magdaleny przez gnostyków szukać należy w tradycji nowotestamentowej. W Ewangeliach kanonicznych jej wywyższenie wiąże się z przeżytą przez nią „,chrystofanią rezurekcyjną"49 oraz z poleceniem przekazania nowiny o zmartwychwstaniu apostołom, które wypełniła. Pisze o tym Jan (20,1-18): „I powiedz im: «Wstępuję do Ojca mego i Ojca waszego oraz do Boga mego i Boga waszegon. Poszła Maria Magdalena oznajmiając uczniom: «Widziałam Pana i to mi powiedział»"50. Wątek Marii Magdaleny jako apostołki apostołów podejmują autorzy takich utworów jak: Ewangelia Marii, Dialog Zbawcy i Ewangelia Filipa. W Dialogu

45 Por. NHC II 2: 37, 23-31, PSP 20, 212: „Spytali Go: «Jeśli staniemy się małymi wejdziemy do królestwa»?. Odrzekł im Jezus: «Wejdziecie, jeśli macie zwyczaj czynić dwa jednością i stronę wewnętrzną czynić tak, jak zewnętrzną [....] i jeśli macie zwyczaj czynić to, co męskie i żeńskie jednościa aby to, co jest męskie, nie było męskie, a to, co żeńskie, nie było żeńskie»".

${ }^{46}$ BG: 17, 10-22; W. Myszor, Ewangelia Marii, s. 158-159.

47 BG: $18,6-12$, tamże.

48 Por. przypis 2.

49 Por. Cz. Bartnik, Maria Magdalena jako „Apostola Apostolorum”, RT 43 (1996) z. 2, 183-190.

${ }^{50}$ Cytat wg Biblii Tysiąclecia; por. też Mt 28, 10. 
Zbawcy Maria Magdalena, w odpowiedzi na pytanie o przyczynę włączenia jej do grona uczniów Zbawcy, otrzymuje od Pana polecenie wyjaśniania prawd objawionych. Nie wiadomo jednak, czy jej misja obejmuje pozostałych uczniów (z grona dwunastu), czy też odnosi się do innych wybranych. W Ewangelii Marii zostają jej powierzone (objawione) tajemnice, których nie otrzymali inni uczniowie, ale bez wyraźnego wskazania przez Zbawcę misji apostolskiej; wydaje się (na podstawie zachowanego tekstu), iz Maria misję tę podejmuje $\mathrm{z}$ inicjatywy samych uczniów:

„Rzekł Piotr do Marii: «Siostro, wiemy, zbawca kochal ciebie bardziej od reszty niewiast, powiedz nam slowa Zbawcy, które sobie przypominasz, to, co ty znasz, a nie my, i czego nie słyszeliśmy». Odpowiedziała Maria mówiąc: «To, co ukryte przed wami, objaśnię wam» ${ }^{51}$.

Jak gnostyccy autorzy wyjaśniali to szczególne wyróżnienie Marii Magdaleny przez Zbawcę? Piotr thumaczy, że Zbawca powierzył Marii pewne tajemnice, ponieważ kochał ją bardziej od reszty niewiast. Lewi rozszerza ten krąg na uczniów (apostołów): „Zbawca [...] ukochał ją bardziej niż nas”. Podobne stwierdzenie znajdujemy w Ewangelii Filipa (II 63, 34-35). Autor pisma wskazuje jednocześnie na przyczyny wyróżnienia Marii przez Zbawcę, wyjaśnia też charakter tej wyjątkowej relacji:

„Inne kobiety [...] powiedziały mu: «Dlaczego kochasz ją bardziej niż nas wszystkie»? Zbawca odpowiedział im mówiąc im: «Dlaczego nie kocham was tak, jak ją? Ślepiec $\mathrm{z}$ widzącym przebywając $\mathrm{w}$ ciemnościach nie różnią się od siebie. Kiedy nastaje światlość wówczas widzący ujrzy światłość, ślepiec pozostanie w ciemności»" ${ }^{32}$.

Odpowiedź Zbawcy jest zatem następująca: Marii Magdalenie należy się szczególne miejsce wśród uczniów, gdyż to wynika z jej wyjątkowych, naturalnych zdolności do pojmowania rzeczy duchowych (stąd pojawiająca się tu symbolika światła). Zdolności te sprawiają, iż wśród uczniów zajmuje ona najwyższe miejsce. Zbawca mówi o tym w formie alegorycznej, porównując Marię do widzącego, zaś pozostałych uczniów do ślepców. Alegoria ta ukazuje istotę gnostyckiego nauczania. Stosując tutaj schemat walentyniański, dzielący ludzi na pneumatyków, psychików i hylików, można powiedzieć, że Maria (w świetle tej wypowiedzi) jest typem pneumatyka - człowieka duchowego, który zdolny jest do poznania rzeczy (i spraw) boskich, gdyż ma tę samą naturę, co one. Jest - idąc za myślą autora Ewangelii Filipa - jak widzący, który, gdy wychodzi z ciemności, zaczyna (w świetle) spostrzegać różne przedmioty, bowiem postrzeganie należy do funkcji jego oczu. Pozostali uczniowie są jak ślepcy; oni, aby poznać potrzebują nauczyciela, przewodnika, ukazującego im drogę. Prze-

${ }^{51}$ BG: 10, 1-6, W. Myszor, Ewangelia Marii, s. 156.

52 NHC II: 63, 36-64, 9, PSP 20, 252. 
wodnikiem tym staje się właśnie Maria. W Pistis Sofia Zbawca mówi wprost o prymacie Marii Magdaleny nad uczniami: „Bowiem Maria Magdalena i Jan i Dziewica będą wywyższeni nad wszystkimi moimi uczniami"

Idea Marii Magdaleny, jako ,apostolae gnosticorum”, w Ewangelii Filipa, Ewangelii Marii i Maqdrości Jezusa Chrystusa wpisana została w gnostycką sofiologię, ukazującą ją jako ziemską reprezentantkę Mądrości Jezusa ${ }^{54}$ :

„Co się tyczy Mądrości, która jest nazywana bezpłodną - ona jest matką aniołów i towarzyszką Zbawcy Marią Magdaleną"55.

Nauka ta wiąże się też z wątkiem trzech Marii ${ }^{56}$ :

„Trzy chodziły z Panem zawsze: Maria, jego matka i jej siostra i Magdalena, ta którą nazywa się jego towarzyszką. Maria bowiem jest jego siostrą i jego matka i jego towarzyszką"s?.

Cały ten fragment podzielić można na dwie części: 59, 6-9 i 59, 10-11. Kluczem do zrozumienia idei Marii Magdaleny, jako reprezentantki Bożej MądrościSofii, jest fragment drugi, który w wersji oryginalnej brzmi następująco: „Mapıa

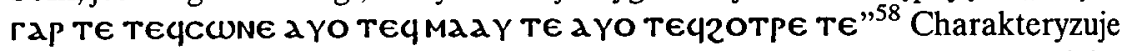
on potrójną w wymiarze duchowym funkcję Marii wobec Jezusa, tzn. jako matki, siostry i towarzyszki ${ }^{59}$. Na duchowy wymiar relacji wskazywałoby slowo 2оTp€ użyte, na określenie towarzyszki (zamiast pojawiającego się wcześniej KoINCNNOc, które określa ziemską jej postać), oznaczające duplikat, zdwojenie $^{60}, \mathrm{~W}$ tym aspekcie Maria stanowiłaby Sofię-Mądrość, czyli żeńską część eonu Jezusa ${ }^{61}$, która wychodząc na zewnątrz stwarza niższy świat duchowy (Sofia jako matka aniołów), kresem jest świat materialny. Fragment 59, 6-9, paralelny do 63, 30-33, odnosi się już do rzeczywistości ziemskiej, w której każdy z aspektów Marii niebiańskiej otrzymuje swoją reprezentantkę. Aspekt Sofii (która nie może już stwarzać, stąd jej określenie „bezpłodna” - cTєıpa) reprezentuje tutaj Maria Magdalena.

${ }^{53}$ Pistis Sofia II: 232, 26 - 233, 2, NHS: CGL 9, ed. C. Schmidt, Leiden 1978, 464-466; A. Marjanen, dz. cyt, , s. 72.

54 J. Janssens, L'Evangile selon Philippe, „Le Muséon” 80 (1967) 91; W. Myszor, Ewangelia Marii, s. 151; L'Evangile de Marie, trad. ed commenté par Jean-Yves Leloup, Paris 2000, 214.

55 NHC II 3: 63, 30-33, PSP 20, 252.

56 Por. W. Myszor, Maryja w wypowiedziach chrześcijańskich gnostyków, WST 10 (1997) 212213.

57 NHC II 3: 59, 6-11, PSP 20, 247.

58 NHC II: 59, 10-11, NHS: CGL 20, ed. B. Layton, Leiden 1989, 158.

59 Podobna idea pojawia się też w gnozie szymoniańskiej, zob. Hippolytus, Refutatio VI 17 , GCS 26, 143, por. też Grzmot: umyst doskonaty, NHC VI 2: 13, 19-21.

60 Por. W.E. Crum, A Coptic Dictionary, Oxford 1979, 726.

61 Por. W. Myszor, Ewangelia Marii, s. 151. 
$\mathrm{Na}$ gruncie tego mitu (funkcjonującego w różnych odmianach w wielu systemach gnostyckich) autorzy omawianych pism, wyjaśniają ostatecznie fakt podniesienia przez Zbawcę Marii Magdaleny do rangi swojej towarzyszki, uczennicy oraz apostołki swego objawienia.

Na podstawie przytoczonych wypowiedzi można stwierdzić, iż gnostyccy autorzy wprowadzili nowe rozumienie pojęcia „ucznia Jezusa (Zbawcy)”. W gnozie zaczęło ono funkcjonować na gruncie mitów o pochodzeniu człowieka duchowego (pneumatyka) i o upadku Sofii; miało też związek z gnostycką soteriologią. $Z$ pojęciem tym wiązała się przede wszystkim elitarność: uczniem Jezusa mógł zostać jedynie ten, kto był tego godny (Ewangelia Tomasza II 2: 43, 33-44, 1), kto pochodził od „Dawcy życia” (Mqqdrość Jezusa Chrystusa III 3: $117,19)$ - innymi słowy gnostyk. Bariery nie stanowiła natomiast płeć, gdyż ta (w świetle gnostyckiej sofiologii) była skutkiem upadku pneumy, w wyniku którego nastąpił wszelki podział. Dlatego też ukazane w utworach kobiety (gnostyczki), takie jak Maria Magdalena czy Salome, na równi z mężczyznami towarzyszyły Zbawcy, zadawały mu pytania i słuchały jego nauki. Stawały się też apostołkami objawionej przez niego prawdy (jak pokazuje to np. Ewangelia Marii) ${ }^{62}$.

Wydaje się, iż poglądy autorów prezentowanych tekstów na temat kobiet stanowiły odbicie profeministycznych nastrojów, jakie dominowały w sektach. Jednocześnie antyfeministyczne wypowiedzi, jakie zostały przedstawione w Ewangelii Tomasza i Ewangelii Marii, mogą nasuwać podejrzenie, iż stanowiska tego nie podzielali wszyscy gnostycy.

\section{A WOMAN: A STUDENT AND TEACHER IN IMPARTING GNOSTIC MESSAGES}

(Summary)

Seven Gnostic writings were discussed in the article: The Gospel according to Thomas, The Gospel according to Philip, The Sophia of Jesus Christ, The Dialogue of the Savior, The I. Apocalypse of the James, The Gospel of Mary and Pistis Sophia.

${ }^{62}$ U Orygenesa pojawia się wzmianka jeszcze o jednej „apostołce gnostyków”- Salome, od której miała pochodzić gnoza karpokracjańska, por. Contra Celsum V 62, SCh 147, 168. 
They represent the mysterious teachings of the Savior, who passed it on to a chosen group of men and women. According to the author, these compositions reflect the factual relationship of Gnostics towards women that is why they constitute an important argument for the issue of women's participation in Gnostic teachings. 